\title{
Bínubo ou Binúbo?
}

\section{Dr. Alexandre Correia}

Tal o título de um pequeno artigo publicado pelo saudoso professor da Faculdade de Direito de São Paulo, o doutor Raphael Corrêa da Silva, na extinta Gazeta Juridica (vol. IX, 1895, pags. 13-15), no qual conclui ser bínubo, com o acento tónico na antepenúltima, a exacta pronúncia dêsse vocábulo.

Ora, parece-me de todo insustentável o raciocínio do ilustre mestre para chegar a essa conclusão. Na minha modesta opinião, a palavra é paroxítona - binúbo e não, proparoxítona - bínubo. 0 que é facil de estabelecer.

Pois, como é sabido, o acento tónico português é regulado pelo latino, em regra geral. Qualquer gramática histórica da nossa língua no-lo ensina. Tomemos, p. ex., a de Ribeiro de Vasconcellos (Lisboa, 1909) e leiamos a pags. 41-2: “O acento tónico, diz, tem importância tão grande na passagem do latim popular para as línguas romanicas, que parece ter sido êle o sustentaculo de toda a palavra. A sylaba tónica permanece...". O leitor poderá vêr inúmeros exemplos e maior desenvolvimento do assunto nêsse mesmo logar.

Ora, isto que é geralmente exacto, em se tratando da línguagem popular portuguesa, o é, com maioria de razão e absolutamente, quando se trata de palavras de formação erudita, como é o nosso caso. 
0 adjetivo binubus, com a penúltima longa (cf. p. ex., o dicionário latino de Freund-Theil), foi empregado pela primeira vez pelo escritor Cassiodoro, da baixa latinidade (490583), na sua Historia Ecclesiastica, onde lemos o seguinte (9.38, ed. Migne): Novatiani circa Phrygiam binubos non recipiunt... Não é, pois, um vocábulo do latim clássico, e é evidentemente um termo erudito formado pelo historiador do $5 .^{\circ}$ século.

E, sendo assim, podemos concluir imediatamente, em virtude da regra supra referida, sem sombra de dúvida, que a pronúncia correcta do vocábulo é binúbo, com a penúltima acentuada, e não, bínubo, proparoxítono, como quer Raphael Corrêa.

Todo o vício da argumentação do ilustre e saudoso mestre está em desconhecer êle a existência do vocábulo latino binubus. Pois, logo no principio do seu artigo diz: "Nem boa latinidade nem a decadente jamais usaram essa palavra, que talvez fosse Teixeira de Freitas que primeiro sagrou"! (grifo meu). E ao terminar o seu estudo afirma, que binubo ou binupto não tem correspondente em latim.

Partindo dêsse falso pressuposto e observando, (pag. 15), que apesar do verbo simples nubo ter a penúltima longa dêle se originaram, contràriamente à regra - derivata patris naturam verba sequuntur, i. é, os derivados têm a mesma quantidade que os simples donde procedem - os adjectives innuba e pronuba, que deram o português ínuba e prónuba, proparoxítonos, observando esse facto, daí concluiu, que também devemos dizer bínubo e não, binúbo, acentuando a penúltima. Mas todo esse arrazoado se esbarronda, desde que mostrámos a existência do latim binubus, com a penúltima longa e que evidentemente não pode dar o português bínubo, exdrúxulo.

Mas, ainda que não existisse, ao contrário do que acabámos de mostrar acima, o latim binubus, ainda, assim a argumentação do sr. Raphael Corrêa seria frágil, como é fácil de ver. 
Retomemos a regra que êle próprio enuncia, à pags. 14 do seu artigo: os compostos seguem a lei dos seus simples. Ora, qual é o simples, donde vem o português binúbo (dandolhe de barato que não existe em latim binubus)? E' o verbo nubo, com a penúltima longa. $\mathrm{E}$, portanto, quem quizesse formar a palavra portuguesa binubo, por hipótese sem correspondente latino, deveria, obedecendo à regra da derivação, acentuá-la na penúltima - binúbo e não, na antepenúltima - binubo!

Mas, acode o sr. Raphael (pags. 14-15), os adjectivos innuba e pronuba (1), com o $u$ breve, que deram o português ínuba e prónuba, proparoxítonos, êsses adjectivos nos autorisam também a dizer bínubo, acentuando a antepenúltima.

Mas, a razão não colhe (sempre na hipótese falsa, que não existe em latim binubus) porque as formações latinas innubus e pronuba e os seus correspondentes exdrúxulos portugueses são anomalias (2); e quem quer formar um novo vocábulo deve atender à regra geral de derivação e não, a casos anómalos. E dizer portanto binúbo, paroxítono, e não, bínubo, proparoxitono.

(1) O Sr. Raphael Corrêa dá as formas dos adjetivos pronubus e pronubum e innubus a, um e o verbo pronubo, que não existem, em latim. Dos adjectivos só há a forma do feminino - pronuba, innuba.

(2) O Sr. Raphael fica visivelmente embaraçado, depois de ter enunciado a regra exacta de derivação latina, que leu em Alvarez, por vier que nubo, como o $u$ longo deu, de um lado e normalmente, innubo e, de outro, as formas anómalas innubus e pronubus (leia-se pronuba) com o $u$ breve! Mas, não devia se admirar do que é tão freqüente em latim. No mesmo Alvarez veria dejero e pèjero, derivados de juro; maledicus, causidicus, veridicus, etc., derivados de dico $\mathrm{E}$ ainda outras anomalias. naturais para quem reflecte que uma língua não se forma geomètricamente.

0 caso de nubo que, tendo o $u$ longo, deu pronuba e innuba, com o $u$ breve explica-se por paridade com cumbere e cubare. Como nubo vem do vocábulo grego numphe, foi sem dúvida a nasal $\mathrm{m}$, que, existindo primitivamente no verbo latino e vindo depois a cair, produziu o alongamento do $u$ (cf. Bréal, Dictionaire Etymologique Latin, vb. nubo; A. Walde, Lat. etym. Wörterbuch, id.; Boisacq, Dict. etym. de la langue grecque, vb. numphe, etc.).

Quanto a explicar a quantidade do u em bin ubus, por ser êsse vocabulo equivalente de bis + nuptus, é obvio que a explicação: nada vale. 
Mas, desde o momento que em latim existe binubus, com a penúltima longa, manter o português bínubo, acentuando a ante-penúltima, seria o mesmo que aceitar êste disparate: assim como, em português, devemos dizer inuba e prónuba, proparoxítonos, porque derivam do latim innuba e pronuba, com o $u$ breve e por tanto proparoxitonos, assim tambem devemos, em português, pronunciar bínubo, proparoxítono, acentuando a antepenúltima, porque (!) deriva do latim binúbus, com o $u$ longo portanto... paroxitono !...

Não haja, pois, a menor dúvida; ou aceitamos as regras certas da derivação latina, que regem o acento tónico português (como aliás as aceita o Snr. Raphael) e então devemos dizer binúbo, acentuando a penúltima, ou dizemos, acentuando a ante-penúltima, como quer o Snr. Raphael, bínubo e então anarquisamos completamente o que ha de mais seguro em matéria fonética portuguêsa. Binúbo, pois, e não, bínubo; o que em Aulete, C. de Figueiredo, Gonçalves Viana e outros dicionários se lê, mandando acentuar a ante-penúltima, bínubo, constitui pronúncia viciosa. 